\title{
Chemical Control of Black Scorch Disease on Date Palm Caused by the Fungal Pathogen Thielaviopsis punctulata in United Arab Emirates
}

Esam Eldin Saeed, Department of Aridland Agriculture, United Arab Emirates University, Al-Ain, UAE; Arjun Sham and Khaled El-Tarabily, Department of Biology, United Arab Emirates University; Firas Abu Elsamen, Department of Aridland Agriculture, United Arab Emirates University; and Department of Plant Production Sciences, Faculty of Agriculture, Jordan University of Science and Technology, Irbid, Jordan; and Rabah Iratni and Synan F. AbuQamar, Department of Biology, United Arab Emirates University

\begin{abstract}
Saeed, E., Sham, A., El-Tarabily, K., Abu Elsamen, F., Iratni, R., and AbuQamar, S. F. 2016. Chemical control of black scorch disease on date palm caused by the fungal pathogen Thielaviopsis punctulata in United Arab Emirates. Plant Dis. 100:2370-2376.

Date palm (Phoenix dactylifera $\mathrm{L}$.) is one of the most important plants grown for its edible fruit. Palm diseases are among the major factors affecting its growth and productivity. In the United Arab Emirates (UAE), the causal agent of black scorch on date palm was found to be Thielaviopsis punctulata. The pathogen was isolated from all tissues of diseased trees affected by the virulent $T$. punctulata. Depending on the severity of the infection, symptoms included tissue necrosis, wilting, neck bending, death of terminal buds, and eventual plant mortality. This fungus, which was consistently isolated on potato dextrose agar from infected tissues, produced two types of conidia: the

thick-walled aleuroconidia (chlamydospores) and phialoconidia (endoconidia). In addition, all target regions of 5.8S ribosomal RNA, 28S ribosomal DNA, $\beta$-tubulin, and transcription elongation factor $1-\alpha$ genes of the pathogen were amplified using polymerase chain reaction. We also found that the fungicide Score inhibited the mycelial growth of $T$. punctulata both in vitro and in vivo. Altogether, the morphology of the fruiting structures, pathogenicity tests, and molecular identification confirmed that the causal agent of symptomatic tissues is T. punctulata. This is the first report of the black scorch disease and the fungus $T$. punctulata on date palm in the UAE.
\end{abstract}

Date palm (Phoenix dactylifera L.) is one of the most important plants in arid and semiarid land that tolerates extreme environmental desert conditions. Date palm trees have significant nutritional and economical value in the Mediterranean, Middle East, Australia, China, North Africa, and warm zones in the United States of America (Zaid and de Wet 1999), in addition to their social and heritage value in the Arabian world, including the United Arab Emirates (UAE) (Mahmoudi et al. 2008). With approximately 5,000 date palm varieties in the world, 'Barhi', 'Hilali', 'Khalas', 'Lou Lou', and 'Makhtoumi' are the most popular date palm varieties in the UAE, with their rich, delicate flavor and taste (Al-Khalifah and Askari 2003). The UAE is one of the top producers and exporters of dates (FAOSTAT; http://faostat.fao.org/site/339/default.aspx). In most reports, the main pathogens associated with palm diseases are fungi and phytoplasma (Carpenter and Elmer 1978).

Black scorch (Medjnoon or Fool) disease is caused by the fungus Thielaviopsis paradoxa (De Seynes) Höhn or T. punctulata (Hennebert) A. E. Paulin, T. C. Harr. \& McNew (de Beer et al. 2014). These fungi have a wide host range, including pineapple, sugarcane, coconut, and palm (Elliott 2006; Sánchez et al. 2007; Singleton et al. 1992). $T$. paradoxa and $T$. punctulata are soilborne wound pathogens that can affect all parts of the date trees at all ages and over a wide geographical area. Black scorch is an important problem confronting the date palm industry, with losses of $>50 \%$ in newly planted offshoots and fruit (Abdelmonem and Rasmy 2007; Gariani et al. 1994). This disease has been reported on date palm in many date-growing areas in the world. Previous studies have identified T. paradoxa as the causal agent of neck bending disease on date palm in Oman (Anonymous 1993), Iraq (Abbas et al. 1997), Qatar (Abbas and Abdulla

Corresponding author: S. AbuQamar; E-mail: sabuqamar@uaeu.ac.ae

*The $\boldsymbol{e}$-Xtra logo stands for "electronic extra" and indicates that four supplementary figures and one supplementary table are published online.

Accepted for publication 5 July 2016.

http://dx.doi.org/10.1094/PDIS-05-16-0645-RE

(C) 2016 The American Phytopathological Society
2003), Saudi Arabia (Al-Sharidy and Molan 2008), Kuwait (Mubarak et al. 1994), Iran (Mirzaee et al. 2014), Italy (Polizzi et al. 2006), and the United States (Garofalo and McMillan 2004). In two recent reports, T. punctulata has been found to be the common pathogen associated with black scorch of date palm in Oman (Al-Sadi et al. 2012) and Qatar (Al-Naemi et al. 2014). Neither of the two Thielaviopsis spp. has been identified in the UAE, despite the occurrence of black scorch disease on date palm.

These fungi often penetrate the leaves, inflorescence, heart, trunk, or bud of palm trees, causing them to rot (Abbas and Abdulla 2003; Al-Raisi et al. 2011; Suleman et al. 2001, 2002; Zaid et al. 1999). Infections are characterized by necrosis of tissues. Lesions are black and hard, and have a charcoal-like appearance. When any of these fungi attacks the terminal bud and heart, the region of infection will "bend", leading to the death of the palm tree. It has also been observed on different date varieties with a variation of susceptibility toward the fungus. Reports have shown that some varieties are highly susceptible (Klotz and Fawcett 1932). Both fungi are commonly found to cause the disease symptoms on palm trees either alone or in combination or associated with other fungal pathogens, including Phoma and Alternaria spp. (Al-Raisi et al. 2011; Shivanathan and Al-Raisi 1996). In vivo studies demonstrated that both $T$. paradoxa and $T$. punctulata colonized palm tissues under drought stress and, eventually, caused plant death (Suleman et al. 2001).

To manage black scorch disease, traditional horticultural practices have been applied under the fungal attack. Avoidance of wounds of trees can limit disease incidence (Chase and Broschat 1993). Infected palm trees should be cut, removed, and burnt. Early infections can also be effectively treated by benomyl. Biological control (i.e., Trichoderma or Chaetomium spp.) can also reduce disease incidence of T. paradoxa in the field (Sánchez et al. 2007; Soytong et al. 2005). Cultural, chemical, and biological integrated programs are highly recommended to manage black scorch. Here, we report a fungicide treatment against $T$. punctulata as an effective practice to reduce economic losses associated with black scorch disease in date palm plantations. Farmers in the UAE, the region, and other date production areas suffering from this devastating disease will directly benefit from this study. Future physiological and molecular analyses will shed more light on black scorch and its causal agents, which will ultimately lead to the development of future protective strategies 
against this disease. In this study, we aimed to determine the etiology of this disease on date palm trees in UAE, and to control T. punctulatainfested date plantations using a curative chemical treatment.

\section{Materials and Methods}

Fungal isolation and purification. Diseased trees were observed in the Al-Wagan area (eastern region of Abu Dhabi Emirate; latitude 24.13, longitude 55.74) exhibiting a complete drying of leaves, with dark or black scorched basal parts (Fig. 1). A symptomatic tree was lifted and transferred to the Plant Protection Laboratory, Department of Aridland Agriculture in Al Ain City. Transverse cross-sections were made using a motorized saw. Below the head of the date palm tree, a section was made where the pith was found to be loose, moist, and rotted. The rotting tissues were found to be highly infested with Physiphora demandata larvae, evident as white spots in Supplementary Figure S1. The fungus was also isolated from these tissues. Tissues were cut into small pieces ( 1 to $2 \mathrm{~cm}$ long), washed, and surface sterilized with mercuric chloride $0.1 \%$ for $1 \mathrm{~min}$, followed by three consecutive washings in sterile distilled water. Then, they were transferred onto potato dextrose agar (PDA; Difco) plates, $\mathrm{pH}$ 6.0, supplemented with penicillin-streptomycin used at a rate of $25 \mathrm{mg} \mathrm{liter}^{-1}$ of growing medium in order to inhibit the bacterial contaminants. Petri dishes were incubated in an incubator at $25 \pm 2{ }^{\circ} \mathrm{C}$ for $96 \mathrm{~h}$. After this period of incubation, the mycelia growing out of the tissue was aseptically subcultured on PDA and, finally, purified by using a hyphaltip isolation technique (Kirsop and Doyle 1991). The mycelium and spores were observed under the microscope (Nikon-Eclipse 50i) connected with a Nikon camera (DS-Flic) to identify different fungal structures. The identified fungus, $T$. punctulata, has been deposited in Leibniz-Institute DSMZ-Deutsche Sammlung von Mikroorganismen und Zellkulturen GmbH (Braunschweig, Germany) under the collection number DSM 102798.

Disease assays and pathogenicity tests. Inoculated whole 'Chichi' date palm seedlings or detached leaf tissues were surface sterilized with $70 \%$ ethanol before spray inoculation with a $T$. punctulata spore suspension of $5 \times 10^{4}$ spores $\mathrm{ml}^{-1}$ on wounds made with a sterile needle to facilitate mycelium penetration. Control plants were sprayed with water using a Preval sprayer (Valve Corp.). Fresh cuttings (from 4- to 5-year-old date palm trees) of the middle parts (20 cm in length) of the offshoot rachis were obtained from the Date Palm Development Research Unit, UAE University (DPDRU). These cuttings were surface sterilized with $70 \%$ ethanol and allowed to dry. Wounds ( $8 \mathrm{~mm}$ in diameter and $4 \mathrm{~mm}$ deep) were made at the end of each cutting of the offshoot frond. These holes were inoculated with a PDA disc ( $8 \mathrm{~mm}$ in diameter), which was cut from a 10-day old culture of T. punctulata, inserted into the hole cuts, and wrapped with parafilm (Molan and El Husseini 1999). Cuttings inoculated with PDA agar plugs without pathogen served as controls. Inoculated fronds were kept in a growth chamber at $25^{\circ} \mathrm{C}$ and 85 to $90 \%$ relative humidity (RH). Inoculated detached fronds were examined for black scorch symptoms after 1,2, and 4 weeks.

Disease was also assayed on whole date palm plants. Twelvemonth-old tissue-cultured date palm seedlings obtained from DPDRU were inoculated with agar plugs ( $8 \mathrm{~mm}$ in diameter) containing mycelium of $T$. punctulata at the leaf base region, where the area of inoculation was wrapped with parafilm. Prior to inoculation, leaf bases were surface sterilized with $70 \%$ ethanol, and mechanical wounding was performed with sterilized scalpels. Control seedlings were treated in the same manner, except that they were inoculated with PDA discs without pathogen to serve as controls. Inoculated seedlings were further kept in a humid growth chamber at $27^{\circ} \mathrm{C}$ and $80 \% \mathrm{RH}$, and were examined for disease symptoms at 1, 2, 4, and 8 weeks postinoculation (wpi). To satisfy Koch's postulates, pieces of inoculated tissues were removed from sites showing disease symptoms at 2 wpi, surface sterilized as mentioned above, and plated on PDA. Plates were incubated at $25 \pm 2{ }^{\circ} \mathrm{C}$ and the subsequent growth was recorded. Disease severity index (DSI) was recorded 1 to 8 wpi using a scale of 0 to 5 , where $0=$ no apparent symptoms and $1=1$ to $10,2=11$ to $25,3=26$ to $50,4=51$ to 75 , and $5=$ 76 to $100 \%$ necrotic or dark brown area around the point of infection (Molan et al. 2004). All experiments were repeated three times with similar results.
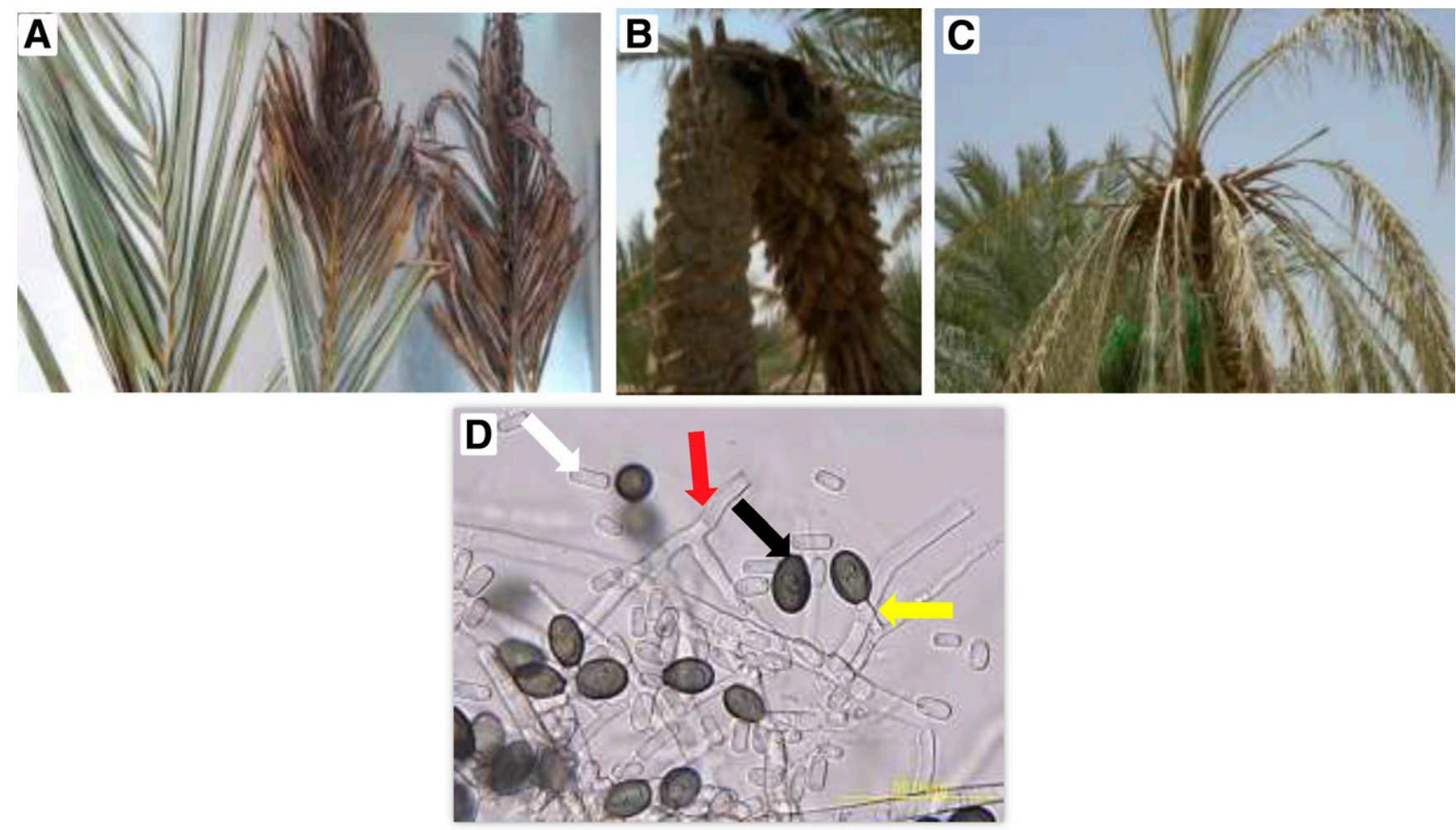

Fig. 1. Symptoms of black scorch disease on date palm and morphological phenotypes of Thielaviopsis punctulata conidia. Symptoms on A, leaves; B, bending of the apical top; C, whole plants; and D, T. punctulata mycelial growth and conidiogenous cells including aleuroconidia and phialoconidia. Red arrow $=$ mycelium, black arrow $=$ aleuroconidia, white arrow $=$ phialoconidia, and yellow arrow $=$ conidiophores 
DNA isolation, polymerase chain reaction, and sequencing. DNA of the pathogen from infected tissues of the leaf, trunk, apical meristem, and pith was extracted from mycelium cultured for 10 to 14 days on PDA plates. DNA extractions were performed using the protocol of using the plant/fungi DNA isolation kit (Norgen Biotek Corp.), with some modifications. Polymerase chain reaction (PCR) was set up to amplify target regions of the internal transcribed spacer (ITS; GenBank accession number JQ963886) of the nuclear ribosomal DNA (rDNA) for $T$. punctulata using ITS1 and ITS4 primers (White et al. 1990), partial 28S rDNA (JQ963885) using LR0R and LR5 primers (Vilgalys and Hester 1990), partial $\beta$-tubulin (JQ963884) using Bt1a and Bt1b (Glass and Donaldson 1995), and partial transcription elongation factor 1- $\alpha$ (TEF1- $\alpha$; JQ963883) using EF1F and EF1R (Jacobs et al. 2004). All primer sequence sets can be found in Supplementary Table S1. All protocols for amplification and sequencing were as described by Paulin and Harrington (2000). Partial sequences of genes were deposited in GenBank: ITS (accession number KT258899), 28S rDNA (KT258900), TEF1- $\alpha$ (KT258901), and $\beta$-tubulin (KT258902).

Phylogenetic analysis. The obtained ITS sequence was further used for constructing the phylogenetic tree against the Ceratocystis spp. database managed by the National Center for Biotechnology Information (http://www.ncbi.nlm.nih.gov). These sequences are: Ceratocystis radicicola (GenBank accession numbers JX518338, AF275492, HM462018, AF043599, and KF953932), C. paradoxa (U75630, AF043607, and AF275477), and C. manginecans (AY953385). Mean character distances were used to construct the neighborjoining phylogeny (Saitou and Nei 1987) using software MEGA V6.0 (Tamura et al. 2013). Sequences were compared and analyzed using the Align function with default gap penalties, and the alignment was manually adjusted where necessary. Phylogenetic trees were constructed and validated with a statistical support of the branches, with 100 bootstrap resamples.

Evaluation of fungicides against $\boldsymbol{T}$. punctulata. The fungicide experiment was carried out as previously described (Jonathan et al. 2012). These fungicides were Ortiva 250 SC (azoxystrobin; Syngenta), Naturame (copper sulfate pentahydrate; SICIT 2000 S.p.A.), Phyton27 (copper sulfate pentahydrate; Phyton Corporation), and Score 250 EC (difenoconazole; Syngenta). Each fungicide obtained a dissolved solution of $250 \mathrm{ppm}$ final concentration in water and was introduced aseptically into sterilized PDA at room temperature (RT) after the introduction of ampicillin to inhibit the bacterial growth. The solution was carefully swirled to attain homogenization status. The resulting mixtures were aseptically dispensed into sterile petri dishes. A sterile cork borer measuring $5 \mathrm{~mm}$ in diameter was used to introduce the tested pathogen onto the control medium (without fungicide) and treatment medium (with fungicide). Cultures were incubated at RT for 4 days, after which radial growth measurements were recorded daily. The percentage of the mycelia growth was measured and growth inhibition was calculated according to the equation $\% \mathrm{MI}=(\mathrm{Mc}-\mathrm{Mt}) / \mathrm{Mc} \times$ $100 \%$, where $\mathrm{Mi}=$ inhibition of the mycelia growth, $\mathrm{Mc}=$ colony diameter (in millimeters) of control set, and $\mathrm{Mt}=$ colony diameter (in millimeters) of the target fungus on the medium with fungicide.

An in vivo evaluation of the fungicide Score was also carried out on 8-month-old Chichi date palm plants. Seedlings were previously inoculated with agar culture discs containing mycelium of T. punctulata at the leaf base region, as described above. Inoculated seedlings were further kept in a humid growth chamber at $27^{\circ} \mathrm{C}$ and $70 \% \mathrm{RH}$ for 4 weeks (until disease symptoms were evident). Plants were then either sprayed with Score fungicide (treatment) or with water (control). DSI was recorded 2 and 4 weeks posttreatment (wpt) using the same scale of 0 to 5 as described by Molan et al. (2004). All experiments were repeated three times, with similar results.

Statistical analysis. For the in vitro evaluation of fungicides against $T$. punctulata, data were analyzed using the analysis of variance (ANOVA) while means were separated using the least significant difference test at a 5\% level of significance. This experiment was repeated in triplicate using five plates per treatment each time, with similar results.

For the T. punctulata disease assay on whole plants and in vivo evaluation of Score, three replicates with a minimum of six plants for each treatment were used. Results were expressed as means \pm standard deviation (SD) of the number of experiments. A Student's $t$ test for the values was performed at $P<0.05$. Data represent the mean \pm SD from a minimum of six plants. ANOVA and Duncan's multiple range test were performed to determine the statistical significance (SAS Institute 1999).

\section{Results}

Disease symptoms of black scorch disease on date palm. Trees that manifested disease symptoms from Al-Wagan, in the eastern region of Abu Dhabi Emirate, UAE, were reported. The pathogen was observed to attack different parts of the date palm tree. First, we noticed the disease symptoms in tissues. When the fungus attacks the leaves, a black, hard, charcoal-like appearance is developed (Fig. 1A). Moreover, when the fungus attacks the terminal bud of the date palm tree, it causes an internal rotting of the pith which may lead to head bending and complete death of the tree (Fig. 1B). This internal pith can also be disintegrated and rotted, with a bad odor. We also determined the disease symptoms associated with black scorch on whole plants in the field.

Date palm trees were heavily affected by the disease in this region. The pathogen attacks the neck of the date palm tree, resulting in other disease symptoms such as complete drying of leaves and death at later stages of invasion (Fig. 1C) and at different ages of date palm trees. These symptoms are typical of the black scorch disease.

Morphological identification of $T$. punctulata associated with black scorch disease. Microscopic examinations of isolates obtained on media and sporulation from affected tissues were performed. We observed mycelial growth and production of two types of spores (Fig. 1D). The first type is known as aleuroconidia or chlamydospores, borne singly on very short hyphal branches; they are thick walled, minutely roughened, pale to dark brown in color, and oval in shape (Supplementary Fig. S2), measuring $16.11 \pm 1.56 \mu \mathrm{m}$ in length. The second is the smooth-walled phialoconidia (also known as endoconidia), which are hyaline to pale brown, cylindrical to rectangular in shape, and formed singly (Fig. 1D) or in chains, measuring (11.01 \pm $0.82 \mu \mathrm{m})$ in length. Our data suggest that $T$. punctulata is most likely the causal organism of black scorch of date palm.

To confirm our results, detached leaflets were spray inoculated with the isolated pathogen (Materials and Methods). Following inoculation, a black rot developed on date palm leaflets after 7 days (Supplementary Fig. S3). Control leaflets remained symptomless. In addition, we performed inoculation on cuttings of offshoot rachis of Chichi date palm. Black lesions on external tissues and light brown areas on internal tissues after splitting the inoculated cuttings were detected after 1 wpi (Fig. 2A). Obvious symptoms of dark brown or black areas developed externally and internally after 2 wpi with $T$. punctulata. Control cuttings showed no symptoms at any time tested.

We also monitored the disease progress on inoculated whole date palm seedlings. Following inoculation, black scorch disease symptoms induced by $T$. punctulata developed first as a browning area on the stem and branches. The first browning appeared on the stem around the site of inoculation $1 \mathrm{wpi}$. The disease progressed rapidly along the stems in the following week and symptoms often were expressed as black scorched leaves (Fig. 2B) and leaf malformation, and characterized by partial to complete necrosis of the tissues (Fig. 2C), and the pathogen was reisolated from the symptomatic tissues. Koch's postulates also confirm that these detected symptoms belong to the same pathogen, T. punctulata (Fig. 2D). At 4 wpi, seedlings showed complete dark brown to black discoloration of stems and branches, forcing the leaves to bend (Fig. 2B and C). At week 8, all plants showed severe discoloration and mortality rate reached to $100 \%$. Control leaf tissues remained symptomless.

Disease severity was recorded and compared with that of leaves and offshoots (Table 1). Statistical analysis of DSI showed highly significant differences among tested tissues for Chichi. At 1 wpi, leaves were recorded as having the highest value in DSI among all tissues tested, with an average of 4.63 , followed by fronds at 1.75 . Clearly, infected seedlings were less susceptible to $T$. punctulata, with an average DSI of 0.63. Damage area around the point of inoculation of the cuttings and whole plants of the tested cultivar 
increased progressively with time, reaching a peak DSI value within 4 and $8 \mathrm{wpi}$, respectively. In comparisons between plant tissues of the same age, our data suggest that leaflets were more susceptible than fronds. Young seedlings averaged a DSI of 4.75 after 8 wpi with T. punctulata.

Phylogenetic analysis of $T$. punctulata. To establish a phylogenic analysis of the isolate obtained in this study, PCR amplification of ITS of the rDNA genes was carried out from mycelium of infected tissues (Fig. 1), plated, and subcultured on PDA. Results from the PCR detected the genes ITS, 28S rDNA, $\beta$-tubulin, and TEF1- $\alpha$ in all infected tissues (Fig. 3A). This confirms that the pathogen $T$. punctulata is frequently associated with all black scorch disease symptoms on date trees.

Because no DNA sequences of this species collected in the UAE were available in GenBank to check and ensure whether this fungus belongs to any $C$. punctulata strain, we tried to identify this strain based on a phylogeny tree. Therefore, the ITS region of the DNA was amplified, sequenced, and deposited in GenBank (accession number KT258899). The generated ITS sequences confirmed its high identity with $C$. radicicola (T. punctulata; Fig. 3B). We also determined the relationship among this obtained sequence and other ITS sequences from available $C$. radicicola and $C$. paradoxa strains. Among the Ceratocystis spp., our analysis revealed that this pathogen is clustered with C. radicicola strains with 99 to $100 \%$ identity, distinguishing this and all C. radicicola isolates from those of C. paradoxa (93 to $94 \%$ identity). C. manginecans was used as the outgroup taxon because it is molecularly and morphologically distinct (van Wyk et al. 2005). Sequence and phylogenetic analyses support that the species $T$. punctulata dominates in the UAE, causing black scorch disease on date palm trees.

Effect of fungicides on mycelia growth of $T$. punctulata. In order to evaluate the effect of fungicides on the mycelial growth of T. punctulata, selected fungicides at $250 \mathrm{ppm}$ were applied in vitro. The data obtained from this study revealed that there was significant difference among the fungicides tested in inhibiting the mycelia growth against the causal agent of black scorch disease, $T$. punctulata
(Supplementary Fig. S4). Accordingly, the results indicated that Score (difenoconazole) inhibited the mycelia growth and sporulation of $T$. punctulata. This result was also confirmed by measuring the mycelium growth inhibition. Although fungal growth could be observed, changes were minimal and clear fungal inhibition zone increased $(>91 \%)$ when Score at $250 \mathrm{ppm}$ was applied (Fig. 4A). An inhibition zone was significantly reduced to 77 to $81 \%$ as the fungicide Phyton or Naturame (copper sulfate pentahydrate) was supplemented; thus, we found no significant difference between Phyton and Naturame. Among fungicides exhibiting a wide range of inhibition, Ortiva (azoxystrobin) at $250 \mathrm{ppm}$ showed virtually no inhibition of fungal growth or sporulation compared with the control (Fig. 4A). This suggests that selective systemic fungicides inhibit the mycelia growth of $T$. punctulata.

To confirm our results, we sprayed Score on diseased seedlings inoculated with $T$. punctulata for 4 weeks, and measured the efficacy of the fungicide for another 4 weeks ( $4 \mathrm{wpt}$ ). Before the treatment with the fungicide, plants showed obvious black scorch disease symptoms. At 2 wpt with Score, plants started to recover (Fig. 4B) and the pathogen was not active enough to cause disease progression (Fig. 4C), which was in contrast to the plants sprayed with water (control). We

Table 1. Disease severity index (DSI) of affected tissues of Chichi date palm at 1,2, 4, and 8 weeks postinoculation (wpi) with Thielaviopsis punctulata $(n=6)$

\begin{tabular}{lccc}
\hline & \multicolumn{3}{c}{ DSI of inoculated tissue $^{\mathbf{z}}$} \\
\cline { 2 - 4 } wpi & Leaflet & Rachis/frond & Seedling \\
\hline 1 & $4.63 \mathrm{a}$ & $1.75 \mathrm{c}$ & $0.63 \mathrm{~d}$ \\
2 & ND & $3.50 \mathrm{ab}$ & $0.88 \mathrm{~d}$ \\
4 & ND & $4.50 \mathrm{a}$ & $3.03 \mathrm{~b}$ \\
8 & ND & ND & $4.75 \mathrm{a}$ \\
\hline
\end{tabular}

${ }^{\mathrm{z}}$ DSI is on a scale of 5 , where $0=$ no infection and $1=1$ to $10,2=11$ to $25,3=$ 26 to $50,4=51$ to 75 , and $5=76$ to $100 \%$ damage necrotic or dark brown area around the point of inoculation. Values with similar letters are not significantly different at $P=0.05$. ND $=$ not determined.

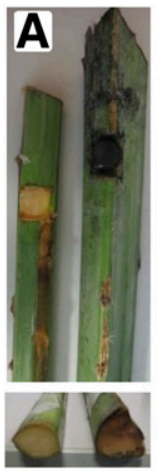

1

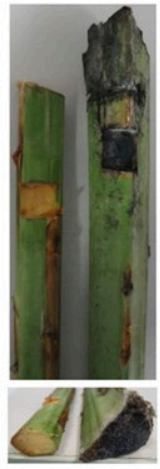

2 wpi

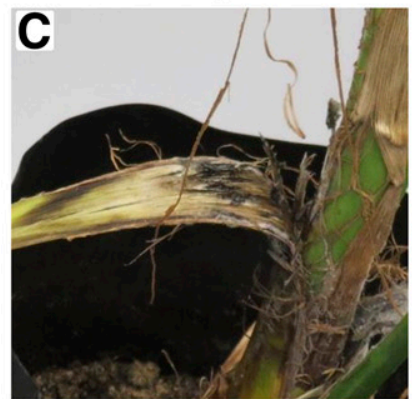

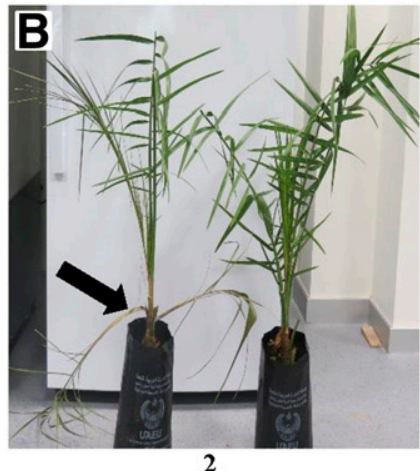

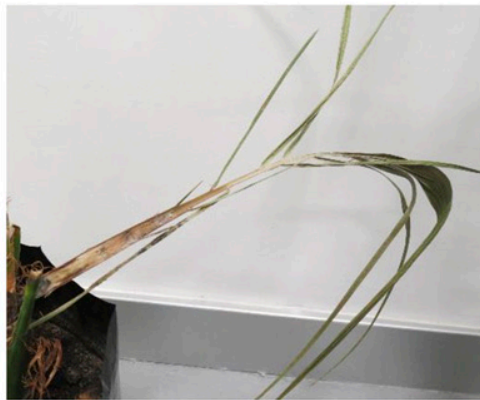

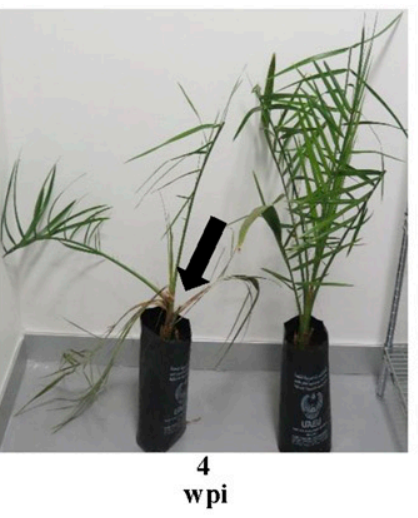
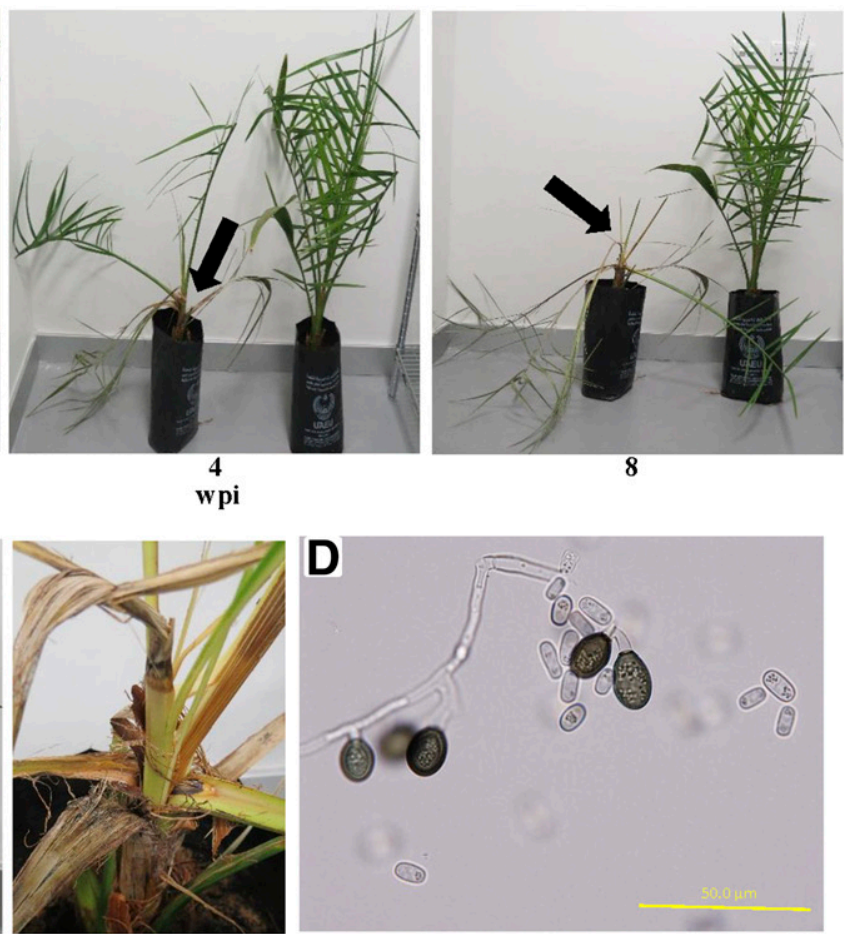

Fig. 2. Pathogenicity test and Koch's postulate test with Thielaviopsis punctulata conidia. Pathogenicity test on A, an inoculated (right) and a noninoculated (left) detached date palm frond (upper panel, top view; bottom panel, side view); B, an inoculated (left) and a noninoculated (right) seedling; C, symptomatic tissues of the inoculated area of the seedling at 2 , 4 , and 8 weeks postinoculation (wpi) (left panel, side view; middle panel, top view; and right panel, bending seedlings); and D, aleuroconidia and phialoconidia after reisolation of the pathogen from affected tissues. 
also observed that new leaves emerged from the heart of date palm seedlings treated with Score but these seedlings were completely dry in untreated samples. There was a drastic decrease in DSI in the Score-treated seedlings at $4 \mathrm{wpt}$ when compared with that of the same plants before treatment or even at $2 \mathrm{wpt}$. However, most control plants were dead at the same time of observation. Our data suggest that this fungicide is highly effective against the fungal pathogen T. punctulata.

\section{Discussion}

Date palm (Phoenix dactylifera $\mathrm{L}$.) is of economic importance and represents a source of income to many farmers in the Arabian Peninsula and countries in North Africa. T. paradoxa and T. punctulata are two pathogens commonly found, either alone or in combination, to cause black scorch disease on palm trees. This disease has been observed in various date-growing areas in the world. Symptoms associated with this disease are mostly expressed as black scorched leaves, trunk rot, neck bending, or inflorescence blight (Fig. 1) (Abbas and Abdulla 2003; Suleman et al. 2001; Zaid et al. 1999). It has been reported that black scorch aggressively appears on date palm trees under drought and salinity stress (Abdullah et al. 2010; Suleman et al. 2001). In the UAE, however, this disease has yet to develop to an epidemic stage, which may lead to widespread death of the palm or to the heavy loss of its
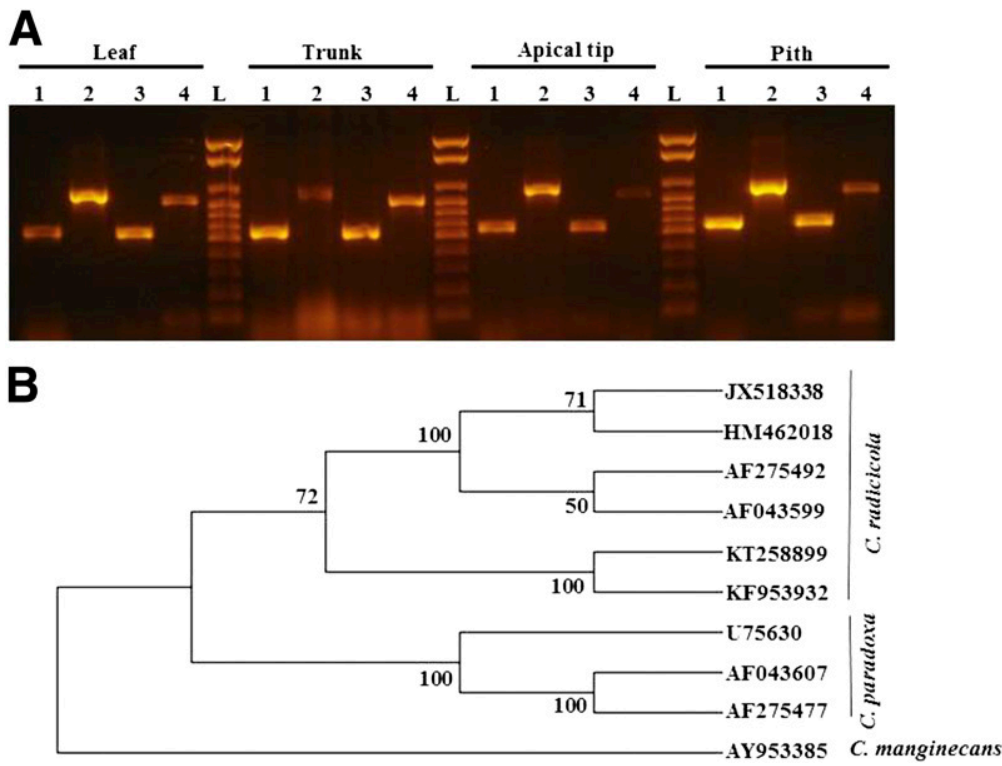

Fig. 3. Molecular identification of Thielaviopsis punctulata. A, Tissue-infected polymerase chain reaction amplification of specific genomic DNA regions. Lanes 1 to 4 correspond to amplifications of internal transcribed spacer (ITS), $28 \mathrm{~S}$ ribosomal DNA, $\beta$-tubulin, and transcription elongation factor $1-\alpha$ regions, respectively; $L=D N A$ ladder. B, Phylogenetic relationship of fungal sequence with the most related ITS sequences in GenBank. The specimen used in this study carries GenBank accession number KT258899. Bootstrap values after 100 replicates are expressed as percentages.

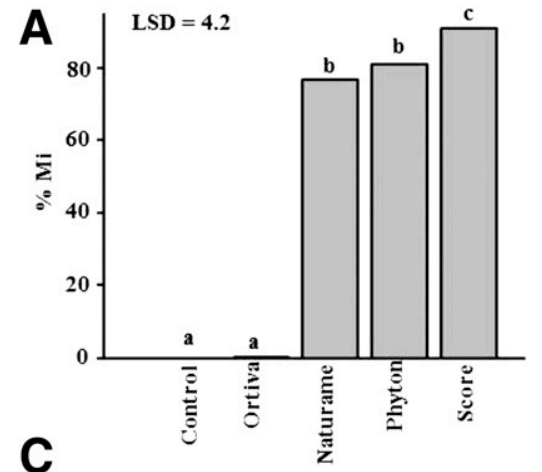

B

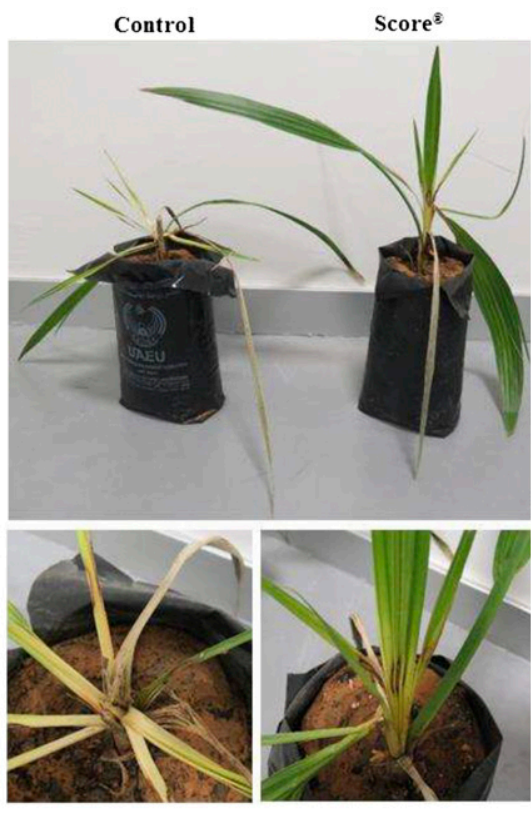

Fig. 4. Efficacy of Score fungicide against Thielaviopsis punctulata. A, Mycelial growth inhibition (\%Mi) of T. punctulata with selected fungicides; LSD = least significant difference. B, Score fungicidal suppression of black scorch disease on date palm. Side view of the heart of (lower, left panel) untreated and Score-treated (lower, right panel) seedlings at 2 weeks posttreatment (wpt). C, Disease severity index of affected tissues of Chichi date palm at 2 wpt with Score $(n=6)$. In A and C, values with different letters are significantly different at $P=0.05$. 
production. Therefore, urgent research is crucially needed for a proper study of this important disease. Here, we aimed to determine the causal agents of black scorch on date palm trees, and to determine a solution to overcome the potentially severe disease of date palm in the UAE.

The pathogen was isolated and identified morphologically and phylogenetically. A fluorescent microscope demonstrated that the pathogen produced an abundance of endoconidia (phialoconidia) and chlamydospores (aleuroconidia) on PDA (Fig. 1D). Consistent with Abdullah et al. (2010), the thick-walled aleuroconidia were borne singly from short hyphal branches, colored pale brown to brownish black. We also observed that phialoconidia were hyaline to pale brown, and cylindrically formed singly or in chains. The length of the two kinds of spores was measured at approximately 16 and $11 \mu \mathrm{m}$ for aleuroconidia and phialoconidia, respectively. We argue that the assessments of spores are of important because they have discrete functions in fungal survival, dispersal, and pathogenicity, despite the difficulty in identifying the species of the pathogen based on its spores. For example, chlamydospores most likely play a role in the survival propagules of the pathogen in soil, which may possibly be involved in infecting the newly transplanted offshoots of date palm trees. In general, our data confirmed previous reports that the mean dimensions of aleuroconidia are often larger than those of phialoconidia in all species that belong to the genus Thielaviopsis (Abdullah et al. 2010; Ammar 2011). In order to avoid any doubts regarding the nature and pathogenicity of the pathogen, leaves, fronds, and whole plants of date palm were inoculated with the isolated pathogen growing on PDA (Fig. 2). The results of inoculation on tissues were similar to the disease symptoms, and the reisolation of the pathogen confirmed Koch's postulates. Our data match with previous pathogenicity tests which have been done on Dracaena (Dracaena marginata), Butia capitata palm, Bottle palm (Hyophorbe lagenicaulis), Kentia palm (Howea forsteriana), and coconut (Cocos nucifera) (dos Santos et al. 2012; Gepp et al. 2013; Pinho et al. 2013; Polizzi et al. 2006; Soytong et al. 2005). The trend of inoculated date palm cuttings found in this study is similar to what has previously been reported (Molan et al. 2004); those inoculated with T. paradoxa at the leaf base became necrotic, wilted rapidly, and died 2 to 3 months after inoculation. Thus, it would be difficult to distinguish between Thielaviopsis spp. based only on their morphology or sporulation. Phylogenetic analysis of amplicons of DNA sequences of the pathogen could provide an alternative identification of the specific pathogen species and fast detection of the black scorch disease on date palm.

Based on the synonymy between $T$. punctulata and Ceratocystis radicicola (Paulin-Mahady et al. 2002), specific genomic regions of $C$. radicicola that correspond to ITS, 28S rDNA, $\beta$-tubulin, and TEF1- $\alpha$ genes were amplified and sequenced. Moreover, a phylogenetic analysis using ITS sequences was set with that of closely related Ceratocystis spp. The most closely related ITS was $C$. radicicola CMW 26389 (KF953932) (Mbenoun et al. 2014), which demonstrated an identity of $99 \%$. Our data also showed that the ITS identified in this study had the highest sequence identity (100\%) with C. radicicola strains DPO1 (HM462018) (Al-Raisi et al. 2011) and IMI316225 (JX518338) (Mbenoun et al. 2014), despite the fact these strains are not the most closely related to the strain phylogeny (Fig. 3 ). Both C. radicicola strains DPO1 and IMI316225 were reported in Oman and Iraq, respectively. Similarly, the ITS (KJ410228) which belongs to $C$. radicicola collected in Qatar showed $99 \%$ identity with CMW 26389, DPO1, and IMI316225 strains (Al-Naemi et al. 2014). None of the ITS sequences that belong to $C$. paradoxa clustered with C. radicicola strains reported worldwide, including the studied ITS (GenBank accession number KT258899), displayed more than 93\% identity. These C. paradoxa strains (U75631, AF043607, and AF275477) were previously reported in the United States (PaulinMahady et al. 2002; Witthuhn et al. 1999). This gives strong evidence that $C$. radicicola (T. punctulata) rather than $C$. paradoxa (T. paradoxa) is, at least, the main causal agent of black scorch in the Arabian Peninsula region in general and the UAE in particular. We also extended our study to potentially control the pathogen.

Although the continuous use of chemicals poses hazards to the ecosystem as well as development of pathogen resistance to these chemicals, many studies urge the use of integrated disease management (IDM). IDM is a program that may use a combination of antagonists such as fungicides, bioagents, and plant extracts to prevent pathogen growth and manage diseases in crops. There are many studies which have focused on biological controls using Trichoderma or Chaetomium spp. against $T$. paradoxa growth (Chakrabarty et al. 2013; Soytong et al. 2005). In their efforts to in vitro test the antagonism of Trichoderma spp. to T. paradoxa, Chakrabarty et al. (2013) have reported that the fungi Trichoderma harzianum and $T$. virens are effective against Thielaviopsis paradoxa. In a field experiment to protect Bottle palm against terminal bud rot disease caused by T. paradoxa, trees sprayed with two Chaetomium spp. (Chaetomium cupreum and C. globosum) completely recovered within 30 days of biological control treatment (Soytong et al. 2005). This suggests that the Trichoderma and Chaetomium biological products are potential bioagents against diseases associated with $T$. paradoxa; thus, both studies have recommended other integrated practices. On the other hand, research in the area of fungicide application against this pathogen is relatively limited. In our efforts to search for a successful fungicide to inhibit T. punctulata, we selected three systemic fungicides (Score, Phyton, and Ortiva) and one contact fungicide (Naturame) and tested their efficacy under in vitro conditions. Score, Phyton, and Naturame were effective in inhibition of the fungus at the tested concentration $(250 \mathrm{ppm})$, whereas Ortiva was not (Fig. 4). Among all chemical-based fungicides, difenoconazole (Score) showed the highest inhibition of mycelial growth, with minor or no tolerance by the organism after 4 days of the in vitro experiment and significant reduction in disease symptoms and DSI on Scoretreated seedlings after 2 to $4 \mathrm{wpt}$. This suggests that this fungicide may serve as a candidate fungicide against $T$. punctulata. The result obtained for difenoconazole (Score) seems to be in disagreement with a previous finding reporting that this chemical did not stimulate the germination of sugarcane seed when infested with $T$. paradoxa $(\mathrm{Croft}$ 1998). This discordance could be attributed to the different growth conditions, fungicide application methods, or strain differences. To a lesser extent, the copper-sulfate-pentahydrate-based fungicides Phyton and Naturame were significantly effective in the reduction of the pathogenic activities of $T$. punctulata compared with the control; 77 to $81 \%$ inhibition to the chemical-based fungicides was recorded on PDA treated with these fungicides. This finding is similar to other reports of a reduction in the radial mycelia growth of $T$. paradoxa using Blitox-50W (copper oxychloride 50\% WP) or other copper-based fungicides (Chakrabarty et al. 2013; Zaid et al. 1999). Thus, Naturame and Phyton are more effective and promising for the control of the woundinvading pathogen $T$. punctulata. On the other hand, the findings obtained for Ortiva (azoxystrobin) yielded disappointing results for black scorch control, supporting the results of other studies (Lassois and de Lapeyre de Bellaire 2014; Willis and Duvenhage 2003).

Reports focusing on biological control have also shown partial or full protection. The biofungicide Mycostop was assessed on Ceratocystis radicicola ( $T$. punctulata) that led to reduced spore germination and sporulations (Suleman et al. 2002). Recently, Al-Naemi et al. (2016) reported a complete control of black scorch disease causal agent $T$. punctulata on date palm using Trichoderma harzianum. In this research, we identified Thielaviopsis punctulata as the causal agent of black scorch disease on date palm in UAE. We also succeeded in finding a chemical means (namely, the fungicide Score) to inhibit $T$. punctulata growth on date palm tress. The investigation of other practices and multiple IDM treatments is underway. Thus, any investment would be suitably rewarded in terms of higher production and sustainable productivity.

\section{Acknowledgments}

We thank K. Sivasithamparam for his critical reading of the manuscript. This project was funded by the UAE University (UAEU) Program for Advanced Research (grant number 21S091) and the Khalifa Center for Biotechnology and Genetic Engineering-UAEU (grant number 31R081) to S. F. AbuQamar.

\section{Literature Cited}

Abbas, E. H., and Abdulla, A. S. 2003. First report of neck bending disease on date palm in Qatar. Plant Pathol. 52:790. 
Abbas, I. H., Al-Izi, M. J., Aboud, H. M., and Saleh, H. M. 1997. Neck bending: A new disease affecting date palm in Iraq. In: (Abstr.) Proc. Sixth Arab Congr. Plant Prot. Congr. Arab Plant Protection Society, Beirut, Lebanon.

Abdelmonem, A. M., and Rasmy, M. R. 2007. Major diseases of date palm and their control. Communications Institut Forestalis Bohemicae, Brno, Czech Republic.

Abdullah, S. K., Lopez Lorca, L. V., and Jansson, H. B. 2010. Diseases of date palms (Phoenix dactylifera L.). Basrah J. Date Palm Res. 9:1-44.

Al-Khalifah, N. S., and Askari, E. 2003. Molecular phylogeny of Date Palm (Pheonix dactylifera L.) cultivars from Saudi Arabia by DNA fingerprinting. Theor. Appl. Genet. 107:1266-1270.

Al-Naemi, F. A., Nishad, R., and Ahmed, T. A. 2014. First report of Thielaviopsis punctulata causing black scorch disease on date palm in Qatar. Plant Dis. 98:1437.

Al-Naemi, F. A., Ahmed, T. A., Nishad, R., and Radwan, O. 2016. Antagonistic effects of Trichoderma harzianum isolates against Ceratocystis radicicola: Pioneering a biocontrol strategy against black scorch disease in date palm trees. J. Phytopathol. 164:464-475.

Al-Raisi, Y. M., B'Chir, M. M., Al-Mandhari, A. M., Deadman, M. L., and Gowen, S. R. 2011. First report of Ceratocystis radicicola associated with date palm disease in Oman. New Dis. Rep. 23:23.

Al-Sadi, A. M., Al-Jabri, A. H., Al-Mazroui, S. S., and Al-Mahmooli, I. H. 2012. Characterization and pathogenicity of fungi and oomycetes associated with root diseases of date palms in Oman. Crop Prot. 37:1-6.

Al-Sharidy, A., and Molan, Y. 2008. Survey of fungi associated with black scorch and leaf spots of date palm in Riyadh Area. Saudi J. Biol. Sci. 15:113-118.

Ammar, M. I. 2011. First report of Chalaropsis punctulata on date palm in Egypt, comparison with other Ceratocystis anamorphs and evaluation of its biological control. Phytoparasitica 39:447-453.

Anonymous. 1993. Status of pests and diseases in Oman. Agricultural Research Centre, Directorate General of Agricultural Research, Ministry of Agriculture and Fisheries, Sultanate of Oman.

Carpenter, J. B., and Elmer, H. S. 1978. Pests and Diseases of the Date Palm. U. S. Dep. Agric. Agric. Handb. No. 527. United States Department of Agriculture, Washington DC.

Chakrabarty, R., Acharya, G. C., and Sarma, T. C. 2013. Effect of fungicides, Trichoderma and plant extracts on mycelial growth of Thielaviopsis paradoxa, under in vitro condition. Bioscan 8:55-58.

Chase, A. R., and Broschat, T. K. 1993. Diseases and Disorders of Ornamental Palms. American Phytopathological Society, St. Paul, MN.

Croft, B. J. 1998. Improving the germination of sugarcane and the control of pineapple disease. Proc. Aust. Soc. Sugar Cane Technol. 20:300-306.

de Beer, Z. W., Duong, T. A., Barnes, I., Wingfield, B. D., and Wingfield, M. J. 2014. Redefining Ceratocystis and allied genera. Stud. Mycol. 79:187-219.

dos Santos, Á. F., Inácio, C. A., Guedes, M. V., and Tomaz, R. 2012. First report of Thielaviopsis paradoxa causing stem rot in Dracaena marginata in Brazil. Summa Phytopathol. 38:345-346.

Elliott, M. L. 2006. Thielaviopsis trunk rot of palm (PP-219). Plant Pathology Department, Florida Cooperative Extension Service, Institute of Food and Agricultural Sciences, University of Florida Davie, FL.

Gariani, N. K., Nuesery, S. M., and Edongali, E. A. 1994. Disease and pest outbreaks. Libya. Black scorch disease of date palms (Phoenix dactylifera) in Libya. Arab Near East Plant Prot. Newsl. 19:40.

Garofalo, J. F., and McMillan, R. T. 2004. Thielaviopsis diseases of palms. Proc. Fla. State Hortic. Soc. 117:324-325.

Gepp, V., Hernández, L., Alaniz, S., and Zaccari, F. 2013. First report of Thielaviopsis paradoxa causing palm fruit rot of Butia capitata in Uruguay. New Dis. Rep. 27:12.

Glass, N. L., and Donaldson, G. C. 1995. Development of primer sets designed for use with the PCR to amplify conserved genes from filamentous Ascomycetes. Appl. Environ. Microbiol. 61:1323-1330.

Jacobs, K., Bergdahl, D. R., Wingfield, M. J., Halik, S., Seifert, K. A., Bright, D. E., and Wingfield, B. D. 2004. Leptographium wingfieldii introduced into North America and found associated with exotic Tomicus piniperda and native bark beetles. Mycol. Res. 108:411-418.

Jonathan, S. G., Udoh, E. M., Ojomo, E. E., Olawuyi, O. J., and Babalola, B. J. 2012. Efficacy of Jatropha curcas Linn. as fungicides in the control of Ceratocystis paradoxa (Chalara anamorph) IMI 501775 associated with bole rot of Cocos nucifera Linn. seedlings. Rep. Opin. 4:48-60.

Kirsop, B. E., and Doyle, A. 1991. Maintenance of Microorganisms and Cultured Cells, A Manual of Laboratory Methods, 2nd ed. Academic Press, London.

Klotz, L. J., and Fawcett, H. S. 1932. Black scorch of the date palm caused by Thielaviopsis paradoxa. J. Agric. Res. 44:155-166.

Lassois, L., and de Lapeyre de Bellaire, L. 2014. Crown rot disease of bananas. Pages 103-130 in: Postharvest Decay. Control Strategies. S. Bautista-Banos, ed. Elsevier. doi:10.1016/B978-0-12-411552-1.00003-X

Mahmoudi, H., Hosseininia, G., Azadi, H., and Fatemi, M. 2008. Enhancing date palm processing, marketing and pest control through organic culture. J. Org. Syst. 3:29-39.
Mbenoun, M., de Beer, Z. W., Wingfield, M. J., Wingfield, B. D., and Roux, J. 2014. Reconsidering species boundaries in the Ceratocystis paradoxa complex, including a new species from oil palm and cacao in Cameroon. Mycologia 106:757-784.

Mirzaee, M. R., Tajali, H., and Javadmosavi, S. A. 2014. Thielaviopsis paradoxa causing neck bending disease of date palm in Iran. J. Plant Pathol. 96:4SUP. doi:10.4454/JPP.V96I4.027

Molan, Y. Y., Al-Obeed, R. S., Harhash, M. M., and El-Husseini, S. 2004. Decline of date-palm offshoots with Chalara paradoxa in Riyadh region. J. King Saud Univ. 16:79-86.

Molan, Y. Y., and El-Husseini, S. 1999. Pestalotiopsis leaf spot of date-palm (Phoenix dactylifera L.) in Saudi Arabia. Alexandria Sci. Exch. J. 20:189-200.

Mubarak, H. F., Riaz, M., Saeed, A. S., and Hameed, J. A. 1994. Physiological studies and chemical control of black scorch disease of date palm caused by Thielaviopsis (=Ceratocystis) paradoxa in Kuwait. Pak. J. Phytopathol. 6:7-12.

Paulin, A. E., and Harrington, T. C. 2000. Phylogenetic placement of anamorphic species of Chalara among Ceratocystis and other ascomycetes. Stud. Mycol. 45:169-186.

Paulin-Mahady, A. E., Harrington, T. C., and McNew, D. 2002. Phylogenetic and taxonomic evaluation of Chalara, Chalaropsis and Thielaviopsis anamorphs associated with Ceratocystis. Mycologia 94:62-72.

Pinho, D. B., Dutra, D. C., and Pereira, O. L. 2013. Notes on Ceratocystis paradoxa causing internal post-harvest rot disease on immature coconut in Brazil. Trop. Plant Pathol. 38:152-157.

Polizzi, G., Castello, I., Vitale, A., and Catara, V. 2006. First report of Thielaviopsis trunk rot of date palm in Italy. Plant Dis. 90:972.

Saitou, N., and Nei, M. 1987. The neighbor-joining method: A new method for reconstructing phylogenetic trees. Mol. Biol. Evol. 4:406-425.

Sánchez, V., Rebolledo, O., Picaso, R. M., Cárdenas, E., Córdova, J., González, O., and Samuels, G. J. 2007. In vitro antagonism of Thielaviopsis paradoxa by Trichoderma longibrachiatum. Mycopathologia 163:49-58.

SAS Institute. 1999. The SAS System for Windows, Release 8.0. SAS Institute, Cary, NC.

Shivanathan, P., and Al-Raisi, Y. M. 1996. Plant Disease Survey of Sharqiyah Region. Directorate General of Agricultural and Livestock Research, Ministry of Agriculture and Fisheries, Muscat, Sultanate of Oman.

Singleton, L. L., Mihail, J. D., and Rush, C. M. 1992. Page 264 in: Methods for Research on Soil-Borne Phytopathogenic Fungi. American Phytopathological Society, St. Paul, MN.

Soytong, K., Pongak, W., and Kasiolarn, H. 2005. Biological control of Thielaviopsis bud rot of Hyophorbe lagenicaulis in the field. J. Agric Technol. 1:235-245.

Suleman, P., Al-Musallam, A., and Menezes, C. A. 2001. The effect of solute potential and water stress on black scorch caused by Chalara paradoxa and Chalara radicicola on date palms. Plant Dis. 85:80-83.

Suleman, P., Al-Musallam, A., and Menezes, C. A. 2002. The effect of biofungicide Mycostop on Ceratocystis radicicola, the causal agent of black scorch on date palm. BioControl 47:207-216.

Tamura, K., Stecher, G., Peterson, D., Filipski, A., and Kumar, S. 2013. MEGA6: Molecular evolutionary genetics analysis version 6.0. Mol. Biol. Evol. 30: 2725-2729.

van Wyk, M., Al-Adawi, A. O., Wingfield, B. D., Al-Subhi, A. M., Deadman, M. L., and Wingfield, M. J. 2005. DNA based characterization of Ceratocystis fimbriata isolates associated with mango decline in Oman. Australas. Plant Pathol. 34:587-590.

Vilgalys, R., and Hester, M. 1990. Rapid genetic identification and mapping of enzymatically amplified ribosomal DNA from several Cryptococcus species. J. Bacteriol. 172:4239-4246.

White, T. J., Bruns, T., Lee, S., and Taylor, J. 1990. Amplification and direct sequencing of fungal ribosomal RNA genes for phylogenetics. Pages 315-322 in: PCR Protocols: A Guide to Methods and Applications. M. A Innis, D. H. Gelfand, J. J. Sninsky, and T. J. White, eds. Academic Press, San Diego, CA

Willis, A., and Duvenhage, J. A. 2003. Progress report on evaluation of alternative fungicides for control of Cercospora spot. S. Afr. Avocado Grow. Assoc. Yearb. 26:45-47, 49

Witthuhn, R. C., Wingfield, R. D., Wingfield, M. J., and Harrington, T. C. 1999. PCR-based identification and phylogeny of species of Ceratocystis sensu stricto. J. Mycol. Res. 103:743-749.

Zaid, A., and de Wet, P. F. 1999. Date palm cultivation. Page 29 in: Origin, Geographical Distribution and Nutritional Values of Date Palm. A. Zaid and E. J. Arias Jiménez, eds. Food and Agriculture Organization of the United Nations (FAO), Plant Production and Protection Paper Number 156, FAO, Rome.

Zaid, A., de Wet, P. F., Djerbi, M., and Oihabi, A. 1999. Diseases and pests of date palm. Page 223 in: Date Palm Cultivation. A. Zaid and E. J. Arias Jiménez, eds. Food and Agriculture Organization of the United Nations (FAO), Plant Production and Protection Paper Number 156, FAO, Rome. 